\title{
From the Mouths of Babes: Children in Recent Indonesian Film and Fiction
}

\author{
Pamela Allen \\ University of Tasmania \\ e-mail:Pam.Allen@utas.edu.au
}

\begin{abstract}
A noticeable trend in recent Indonesian fiction and film has been the use of children as protagonists. This paper examines the role of children in Andrea Hirata's 2005 novel Laskar Pelangi (Rainbow Warriors) and the 2006 film Denias, directed by John de Rantau. I argue that, like the German Bildungsromane, these texts belong to a genre that might be called 'coming of age' or quest narratives. And yet, importantly, they are not just about the personal experience of finding one's place in the world; the young protagonists of these texts also carry the weight of nation-building on their slender shoulders. The texts are not, therefore, simple derivations from European Bildungsromane, but are shaped by colonialism and globalization.
\end{abstract}

Key words: Indonesian fiction, Indonesian film, children, Bildungsromant, quest narratives

A noticeable trend in recent Indonesian fiction and film has been the use of children as protagonists. Usually underprivileged, these children often become a site of socio-political resistance, as they confront hardship, injustice and violence in their daily lives. This paper examines the role of children in Andrea Hirata's 2005 novel Laskar Pelangi (Rainbow Warriors) and the 2006 film Denias, directed by John de Rantau. My paper draws on an eclectic range of sources, including readings of Catullus and Vergil, Walt Whitman and William Wordsworth, Joseph Campbell's work on mythological heroes and analyses of the German Bildungsroman, to argue that these texts belong to a genre that might be called 'coming of age' or quest narratives. And yet, importantly, they are not just about the personal experience of finding one's place in the world; the young protagonists of these texts also carry the weight of nation-building on their slender shoulders. The texts are not, therefore, simple derivations from European Bildungsromane, but are shaped by colonialism and globalization. 


\section{THE STORIES}

Denias Senandung di Atas Awan (Denias Singing on the Clouds), is based on a 'true story.' Denias, the lead character, is a Papuan boy driven by the desire to further his education, a mission that is impossible in his tiny mountain village in the Wamena region. His quest takes him on an arduous physical journey to Kuala Kencana, near Timika. Part of the movie's edginess derives from the fact that much of the shooting of the film took place in and around the domain of Freeport Indonesia's copper and gold mining operations. The school scenes were all shot at the Kuala Kencana School, one of two schools managed for Freeport by the Yayasan Pendidikan Jayawijaya. ${ }^{*}$ The other presence in the film is the place of Papua within the Indonesian state, an issue occasionally alluded to in veiled terms, but not addressed explicitly.

Also a "true story", Laskar Pelangi is based on the writer's own experiences. It is about an inspiring teacher, Bu Mus, and her 10 students in the poor Muhammadiyah school in Kampung Gantong ("the richest village in Indonesia, kampung terkaya di Indonesia", Laskar Pelangi [hereafter LP], p. 49) in the island of Belitong. When the novel opens the school is under threat of closure by the Department of Education unless it can reach ten enrolments. At the eleventh hour, just as the principal Pak Harfan is about to announce the school's closure, the late arrival Harun saves the day. Like Denias, much of the tension of the novel derives from the presence in Belitong of the giant tin mining company PN Timah. The mining company's well-equipped school (a "center of excellence" LP, p. 57) is attended by a different class of students than those who go to the Muhammadiyah School, and the difference in class, wealth and ethnicity between the students who attend the respective schools is the source of much of the action and dramatic tension of the novel.

\footnotetext{
* It is hard to imagine a starker contrast between Denias's remote village and the facilities provided for Freeport employees at Kuala Kencana. To quote Freeport's website: 'Facilities found in the KK township consist of a community centre housing a coffee shop, Hero Grocery Store (a well known Asian grocery store chain), Guardian Pharmacy, Hero Department Store, a hairdresser, a very well equipped state of the art gymnasium, a couple of restaurants, a community library and a hall facility. There is a world class PGA golf course and facilities at KK. This provides a focal point for some of the social activity in the town. The proximity to the Hotel Rimba Papua allows for alternative social activities as does the excellent swimming complex situated near the school grounds.'
} 


\section{BILDUNGSROMAN}

The Bildungsroman is a novel whose principal subject is the moral, psychological, and intellectual development of a usually youthful main character. In essence, the Bildungsroman is "the history of a young man who enters into life in a blissful state of ignorance, seeks related souls, experiences friendship and love, struggles with the hard realities of the world and thus armed with a variety of experiences, matures, finds himself and his mission in the world" (Hardin, 1991, p. xiv). The path to Weltanschaung (a comprehensive conception or apprehension of the world especially from a specific standpoint) is often enlivened by "adventurous episodes" (Bruford, 1975, p. 30).

As Caton (1996) reminds us, the "coming of age" discourse is a common literary convention, featuring stories in which a sensitive childhero begins his life in a provincial area where he quickly perceives constraints on his "natural" development. He grows frustrated with his family, school, and friends. Finally, at a fairly early age, he leaves the repression of home for the "real" education that occurs in a sophisticated, worldly and often urban setting. The hero then takes his youthful innocent unity, his "naturalness" on a quest of maturation that leads him in turn to question and yearn for the inevitable "lost innocence" of family and intimate society (pp. 125-126).

In his classic work The hero with a thousand faces, Campbell (1971) wrote about the "standard path of the mythological adventure of the hero" being a magnification of the formula represented in the rites of passage: separation-initiation-return (p. 30). He gave examples of heroic quests from a diversity of cultures and texts - Asian, Greek, Biblical - in which the hero follows the pattern of separation from the world, a penetration to some source of power, and a life-enhancing return (p. 35).

While clearly emanating from the European literary tradition, the term Bildungsroman has been used in the Indonesian context, the most obvious example being Pramoedya's Buru quartet, which, as Anderson (1998) observed: "has many of the appurtenances of the classical European Bildungsroman...They show the reader how a privileged, highly educated, young Javanese man...gradually develops a national consciousness and conscience, thanks to a wide variety of foreign and indigenous teachers; and how this experience leads him to originate the nationalist movement" (p. 337). Writing in Time magazine, Skow (1996) described the quartet as 
"a bildungsroman, a novel of education...Minke...excels as a token native student at an elite Dutch-language high school. But his true education.... is in the realities of racial and economic oppression."

As a sort of 'heroic quest', the Bildungsroman covers a range of themes, including the ideals of innocence, the deception of the adult world, hardship, violence and injustice. Buckley (1974) suggests that the principal elements of the Bildungsroman are "childhood, the conflict of generations, provinciality, the larger society, self-education, alienation, ordeal by love, the search for a vocation and a working philosophy" (p. 18). While almost all these elements are present in both Denias and Laskar Pelangi I focus here on just two: the trope of the journey, and the unrivalled importance of education. The significant postcolonial 'twist' to each of these elements is their link to the ongoing project of nation-building in Indonesia.

\section{THE HEROES}

But I turn first to the protagonists themselves. The protagonist of the Bildungsroman will more often than not be orphaned, or at least fatherless. If the father is still alive, then in all likelihood he will repel the child and seek to thwart his desires. This loss of the father, whether by death or by alienation, usually symbolises or parallels a loss of faith in the values of the hero's home and family. This in turn leads inevitably to the search for a substitute parent or creed (Buckley, 1974, p. 19).

In Denias it is not the father but the mother who dies, and Denias must carry the burden of guilt that she dies in a fire that starts due to his carelessness. Subsequent to his mother's death, Denias's fractious relationship with his father, Samuel, deteriorates. Unlike the views of his mother, for Denias' father, schooling is something that must take second place to the important things in life. This rift with his father is compounded further by the loss of other father figures in Denias's life. First his teacher, referred only to as "Pak Guru", who returns to Java ostensibly because his wife is ill, but perhaps closer to the truth is his disillusionment with the futility of trying to teach a bunch of rowdy Papuan boys in a thatched roof hut. Then Maleo, the soldier based in the kampong, who takes on the job of teaching the boys, must return to Java. Denias feels betrayed by all the adult male figures in his life.

Although narrated by Ikal, Laskar Pelangi does not have one single protagonist-rather the 'rainbow warriors' of the title, Ibu Mus's ten 
charges, are a sort of 'united' protagonist. Of the ten, it is Lintang's story that has captured the attention of the reading public, with his daily 40 kilometer bicycle ride from his tiny fishing village just to get to school, dodging swamps and crocodiles on the way. While not alienated from his father, who in fact supports his schooling, it is his father's illiteracy that spurs Lintang on to complete his schooling despite extraordinary challenges. At the end of the story, however, Lintang's father dies and Lintang must quit school in order to support his family. The loss of the father, then, is the ultimate thwarter of his desires.

\section{JOURNEY}

Frye (1963) tells us that the quest is the "central myth of literature" (p. 18). In his study of journey in the African epic, Kunene (1991) identifies the purpose of the journey as being a search for the answer to the question 'Who am I?' The journey creates tension in a text because the point of departure constantly exerts a magnetic pull on all the other points of the circular movement, drawing back to itself that which it is simultaneously rejecting, that which is going away, namely the hero (p. 205). Of particular relevance to Denias's story is Buckley's assertion (1974) that the journey from home is also in some degree the flight from provinciality: "The hero...enters the city... with bewilderment and naiveté, and the city plays a double role in his life: it is both the agent of liberation and a source of corruption" (p. 20). That the journey will play a significant role in Denias's life is signalled in repeated early footage in the film of Denias chasing the helicopter as it leaves the village after dropping off supplies. The helicopter's trajectory over the mountain can be read as a metaphor for Denias's own forthcoming journey. As his mother tells him "You can study in that school behind the mountain."

Dick Whittington-like, Denias sets off with his meager possessionsincluding his prized soccer ball-in his string bag, on a journey of epic proportions. Under rainbows, over rocky outcrops, through raging rapids and tropical rainforests, foraging and killing cuscus for food, he walks for four days in bare feet until he reaches his destination, the impossibly pristine town of Kuala Kencana with its impeccably dressed teachers and students and its clean and orderly buildings. The symbolism speaks for itself. 
A secondary journey, and one no less compelling than Denias's, is that of his new friend Eros, who walks kilometres to his home village to get his report book, a requirement for him to be able to enrol in school. And at the end, suitably Indonesianised in his smart red and white uniform, Denias returns to his village and meets up with his old friends, also neatly dressed in their red and white uniforms-the "life-enhancing return" alluded to by Campbell.

For the Laskar Pelangi the journey of self-discovery is represented in the perilous trip by sea to Lanun Island to meet the paranormal Tuk Bayan Tula, with a particular mission to help two of their number, Flo and Mahar, to find the secret to improving their school results (which have been plummeting on account of their obsessive involvement in a secret mystical society called Societiet de Limpai). Aboard an unseaworthy boat, scaling mountainous waves, battling seasickness and under threat of lightning strike, the adventurers eventually reach their destination where, in the mouth of his cave, they meet the supernatural Tuk who must then fight a horde of demons to try to find the answer to Flo and Mahar's dilemma. While the magical realist journey may not be in the best traditions of the German bildungsroman, the prosaic message Tuk presents them with on a piece of paper is: "If you want to pass your exams: Open your books, and study!" [Kalau ingin lulus ujian: Buka buku, belajar!!] (LP, p. 424). They return to Gantong, chastened but wiser.

\section{EDUCATION (BILDUNG)}

Right at the beginning of the film, Denias alludes to the role the looming mountains will play in his heroic quest. His mother has told him that if he neglects his studies, the mountains will eat him up. If he studies hard, however, the mountains will be afraid of him. And so his imaginary journey begins well before the physical one does. Later his mother, ill with fever, imparts her wish for her son by imploring him to study hard in school so that she will get well.

Denias remains unconvinced by Maleo's assertion that "You can get education anywhere, belajar bisa dimana saja". For Denias the value of education is embodied in the person of the teacher. While we might read his journey in the spirit of the bildungsroman, for Denias and possibly for the film-makers, it is his teachers - Pak Guru and Maleo, in the village and 
$\mathrm{Bu}$ Sam at the Kuala Kencana School - who are the providers of his learning.

A similar awe for the role of teachers is found in Laskar Pelangi, with $\mathrm{Bu}$ Mus and Pak Harfan held in the highest of esteem. They are "mentors, guards, friends, educators and spiritual leaders" [mentor, penjaga, sahabat, pengajar, dan guru spiritual] (LP, p. 32) and Ikal likens them to the fern trees (pohon filicium) that "give life to thousands of organisms and represent a key link in the ecosystem chain" [memberi napas kehidupan bagi ribuan organisme dan menjadi tonggak penting mata rantai ekosistem] (LP, p. 33).

\section{NATION BUILDING}

As alluded to above in references to the prevalence of national symbols in Denias and Laskar Pelangi, education and nation building play a symbiotic role in Indonesia. The homepage of the Indonesian Department of National Education (Mendiknas) makes this quite explicit: "the object of the development of education is a society as an entity of the nation" [Obyek pembangunan pendidikan adalah masyarakat sebagai entitas suatu bangsa]. In both Denias and Laskar Pelangi nation-building is developed through predictable tropes.

Denias is a catalyst within his family for understanding what 'Indonesia' is, exemplified perfectly in a classroom exercise in which the children have to construct a map of Indonesia using wooden jigsaw pieces. ("The islands must be liend up like this, Susunannya harus begini," instructs Maleo). There is an overwhelming sense of Java as the unseen mysterious metropolis. Samuel reminds Denias and Maleo that "this is not Java here" (sini bukan Jawa). Despite the remoteness of Denias's Papuan village, the national symbols dominate-the flag flies outside the makeshift school, the boys sing the national anthem. (The flagpole survives an earthquake that destroys the school and does significant damage to the village.) While superficially relatively benign symbolism, this could be read on another level as a challenge to separatist stirrings in Papua. It is hard to escape the fact, too, that the Kuala Kencana School is staffed by Javanese teachers.

The process of nation building goes hand in hand with modernising, and the symbols of modernity-helicopters, candies, toothpaste-are sprinkled judiciously throughout the village scenes. We see conflict 
between traditional Papuan values, as represented by the fathers of Denias and of his friend Noel, and modern values, as represented by Pak Guru and Maleo.

Throughout Indonesia the most significant day as far as nationbuilding goes is, of course, 17 August, Indonesian Independence Day. In Laskar Pelangi the students devote an inordinate amount of time, energy and imagination on preparations for the 17 August carnival, at which the Muhammadiyah School must compete against the vastly better equipped, resourced and talented PN Timah School. However, against the odds, under the artistic direction of Mahar, the Muhammadiyah School wins the competition, wresting the trophy from the halls of PN Timah. For the Laskar Pelangi crew, the victory means that their school "will never again be humiliated" [tak 'kan membuat sekolah kami dihina lagi] (LP, p. 247). In terms of nation-building it can be read as an affirmation of the role of the rakyat, the 'little people' in the development of Indonesia.

To gloss Berlant (1997), who speaks of subaltern bodies and identities bearing the burden of representing "desire for the nation" (p. 27), we might argue that the children in these texts are representing the desire for the nation. While a detailed discussion of national identity politics is beyond the scope of this paper, I am drawn to Berlant's notion of the "infantile citizen". She uses it to describe a certain sort of tyranny that democracies exert that produces citizens who are infantilized and "over dependent on the 'immense and tutelary power' of the state." While she is not literally referred to children as citizens, one might argue that the flag-waving, songsinging, uniform-wearing children in Denias in particular are, literally, "infantile" citizens.

\section{CONCLUSION}

Heavily autobiographical, these texts are subject, to use Buckley's term (1974), "to intrusions from other areas of the author's experience beyond the dramatic limits of the fiction" (pp. 23-24). This can be both a strength and a weakness. Whether or not we read them as Indonesianized Bildungsroman, both texts fall into the trap of presenting an essentialized and frequently sanitized account of education, and nation-building. While their escapades are undeniably entertaining, the task demanded of the children in the film and the novel, as infantile citizens shaping the values of the future of the Indonesian nation, seems somehow too idealized, too propagandized. 


\section{REFERENCES}

Anderson, B. (1998). The spectre of comparisons. London and New York: Verso. Andrea Hirata (2005). Laskar Pelangi. Yogyakarta: Bentang Pustaka.

Berlant, L. (1997). The Queen of America goes to Washington city. Durham: Duke University Press.

Bruford, W.H. (1975). The German tradition of self-cultivation, London: CUP.

Buckley, J. (1974). Season of youth: The Bildungsroman from Dickens to Golding. Cambridge, Massachusetts: Harvard University Press.

Campbell, J. (1971). The hero with a thousand faces. Princeton: Princeton University Press.

Caton, L. F. (1996). Romantic struggles: The Bildungsroman and mother-daughter bonding in Jamaica Kincaid's Annie John'. MELUS, 21(3), 125-142.

Frye, N. (1963). Fables of identity: Studies in poetic mythology. New York: Harcourt, Brace and World.

Hardin, J. (Ed.). (1991). Reflection and action: Essays on the Bildungsroman. Columbia: University of South Carolina.

Kementerian Pendidikan Nasional Republik Indonesia. Retrieved July 12, 2011 from http://www.kemdiknas.go.id/kementerian/kementerian-pendidikannasional.aspx.

Kunene, D.P. (1991). Journey in the African epic, Research in African Literatures, 22(2), 205-223.

Skow, J. (1996, June 24). Setting free the word. Time. Retrieved July 12, 2011, from http://www.time.com/time/magazine/article/0,9171,984884,00.html. 